\title{
Continuous Repetitive Stimuli Are More Effective than Bursts for Evoking LHRH Release in Bullfrog Sympathetic Ganglia
}

\author{
Yan-yi Peng and John P. Horn \\ Department of Physiology, University of Pittsburgh School of Medicine, Pittsburgh, Pennsylvania 15261
}

\begin{abstract}
Effects of different patterns of presynaptic stimulation upon release of leuteinizing hormone releasing hormone (LHRH) were studied by monitoring LHRH-induced slow currents from individual postsynaptic neurons in bullfrog sympathetic ganglia. LHRH-mediated synaptic currents in ganglionic $B$ and C neurons were recorded by a single-electrode voltage-clamp technique. Using continuous stimulation, release increased with frequency between 2 and $20 \mathrm{~Hz}$, then declined. Though bursts of stimuli always evoked more release than continuous stimuli of the same average frequency, they were invariably less effective than continuous stimulation at the intraburstal frequency. This demonstrates that frequency, not bursting structure, governs peptide release. The dependence of release upon stimulus frequency was altered when extracellular $\mathrm{Ca}^{2+}$ concentration was changed, implying that release does not depend intrinsically upon stimulation frequency, but simply on the availability of $\mathrm{Ca}^{2+}$.
\end{abstract}

Neuropeptides are coexpressed with classical transmitters in many central and peripheral neural circuits. Peptides act on neurons to alter $\mathrm{K}^{+}$currents (Adams et al., 1982b; Jan and Jan, 1982; Mihara et al., 1987; North et al., 1987; Griffith et al., 1988; Jacquin et al., 1988; Bosma and Hille, 1989), $\mathrm{Ca}^{2+}$ currents (Mudge et al., 1979; Gross and Macdonald, 1987; Bley and Tsien, 1988; Schofield and Ikeda, 1988; Ewald et al., 1989; Ikeda and Schofield, 1989), repetitive firing properties (Jan and Jan, 1982; Dodd and Horn, 1983b; Dekin et al., 1985; Jones, 1985), and transmitter release (Mudge et al., 1979; Lundberg and Stjarne, 1984). Despite the prevalent existence of neuropeptides and their profound roles in modulating neuronal activities, the mechanism and dynamics of peptide release remain generally unclear. Bccause peptidergic responses tend to have long durations, and because repetitive stimuli are usually required to evoke peptide release, the stimulus dependence of neuropeptide release has been inferred primarily from the collection of transmitters and measures of end-organ function.

Repetitive stimulation with relatively brief high-frequency bursts (e.g., 1-2 sec, 10-20 Hz) that are punctuated by resting periods $(\mathrm{e} . \mathrm{g} ., 9 \mathrm{sec})$ has been reported in several systems to be

\footnotetext{
Received Mar. 6, 1990; revised July 20, 1990; accepted Aug. 30, 1990.

This work was supported by postdoctoral fellowships to Y.P. from the Pennsylvania Affiliate of the Amcrican Heart Association and from NIMH Training Grant MH18273, and by NIH Grants NS21065 and NS01427 to J.P.H. We thank Dr. Eric Frank for sharing his computer programs for data acquisition and analysis and Ms. Patricia Wohlfarth for photographic assistance.

Correspondence should be addressed to Dr. Yan-yi Peng, Department of Physiology, University of Pittsburgh, School of Medicine, El 440 Biomedical Science Tower, Pittsburgh, PA 15261.

Copyright (C) 1991 Society for Neuroscience $0270-6474 / 91 / 010085-11 \$ 03.00 / 0$
}

more effective for evoking peptide release than continuous stimulation at the same average frequency (Andersson et al., 1982; Bicknell et al., 1982; Lundberg et al., 1986, 1989). However, these experiments have not established whether the efficacy of bursting patterns is due simply to the high frequency of stimulation during the bursts or to the inclusion of resting periods between bursts. The former mechanism would be analogous to frequency facilitation of release that has been studied extensively for classical transmitters (reviewed by Barrett and Magleby, 1976; Silinsky, 1985; Zucker, 1989). Alternatively, resting periods might enhance peptide release by allowing for recovery from depression of release. Examples of processes that would theoretically depress release are the depletion of releasable peptide stores and the inactivation of presynaptic $\mathrm{Ca}^{2+}$ channels (Hirning et al., 1988). The possible importance of resting periods is supported by work on hypothalamic neurons where inclusion of very long quiescent periods (21-180 sec) between very long periods of high-frequency stimulation $(25 \mathrm{sec})$ enhances both hormone release (Cazalis et al., 1985) and intracellular $\mathrm{Ca}^{2+}$ accumulation (Brethes et al., 1987). However, it is unclear whether the mechanism of peptide release is conserved for different peptides and synapses. In the present experiments, we have utilized a well-defined peptidergic synapse to examine the dependence of evoked release upon stimulus frequency, upon resting periods between brief bursts of stimuli, and upon the extracellular concentration of $\mathrm{Ca}^{2+}$.

In the bullfrog, the preganglionic $\mathrm{C}$ input to sympathetic ganglia 9 and 10 coreleases $\mathrm{ACh}$ and leuteinizing hormone releasing hormone (LHRH; Jan et al., 1979; Jan and Jan, 1982). LHRH produces a late slow EPSP in $B$ and $C$ postganglionic neurons due mainly to the blockade of a voltage-dependent $\mathrm{K}^{+}$ current, the M-current (Jan ct al., 1980b; Adams ct al., 1982b; Jan and Jan, 1982; Jones, 1987). In this study, LHRH release from the preganglionic $\mathrm{C}$ pathway was monitored indirectly by measuring the magnitudes of excitatory postsynaptic currents (EPSCs) recorded from ganglionic $\mathrm{B}$ and $\mathrm{C}$ cells with a singleelectrode voltage clamp. When various stimulation patterns were compared, we found that LHRH release is more sensitive to stimulus frequency than to burst structure. Furthermore, this frequency dependence can be shifted by altering the extracellular concentration of $\mathrm{Ca}^{2+}$.

A preliminary account of these experiments has appeared (Peng and Horn, 1989).

\section{Materials and Methods}

Intracellular recording. Preparations of paravertebral ganglia 7-10 were isolated from 12-18-cm bullfrogs of both sexes, then set up for intracellular recording as described by Dodd and Horn (1983a). Three suction electrodes were applied to the preparation for stimulation of the pre- 
ganglionic B (chain above ganglion 7) and C (spinal nerves 7 and 8) pathways, and for antidromic stimulation (sciatic plexus). All experiments were conducted at room temperature $\left(20-24^{\circ} \mathrm{C}\right)$. Microelectrodes were filled with $3 \mathrm{M} \mathrm{KCl}$ and were beveled (BV-10, Sutter Instruments) to resistances of 10-25 M . Membrane potentials and currents were measured with a Dagan 8100 single-electrode voltage-clamp amplifier Impaled cells were classified as fast B, slow B, or C-type (Dodd and Horn, 1983a) and were accepted for study only if they had a resting potential negative to $-40 \mathrm{mV}$ and an input resistance greater than 25 $\mathrm{M} \Omega$.

The LHRHergic slow EPSP has a complex voltage dependence because it is generated primarily through suppression of a voltage- and time-dependent $\mathrm{K}^{+}$current, the M-current, which also introduces a marked nonlinearity into the steady-state $I-V$ rclation in the region of the normal resting potential (Adams et al., 1982a). To eliminate the effects of voltage upon postsynaptic potentials, postsynaptic currents were measured by clamping cells at their resting potentials using a singleelectrode voltage clamp. Clamp parameters were set according to Finkel and Redman (1985). For most cells, the switching frequency was $3 \mathrm{kHz}$ with a 0.5 duty cycle. The unclamped voltage was less than $3 \mathrm{mV}$ for the largest EPSC in a given cell. Because the largest EPSCs were evoked by high-frequency continuous stimulation, errors in the clamp resulted in an underestimate in the steepness of the frequency-response relationship. On the other hand, the unclamped voltage increases the amount of M-current available for suppression. This would have the opposite effect of overestimating the largest EPSCs, but only if these EPSCs are maximally suppressing the M-current. However, this factor did not confound the data because the largest EPSC in any given cell suppressed less than $50 \%$ of the available M-current (see below), and the largest voltage errors $(3 \mathrm{mV})$ would only increase the available M-current by less than $15 \%$ at resting potentials used. [This is calculated from data of Adams et al. (1982a,b)].

Nerve stimulation parameters. Several ganglion cells were briefly impaled at the start of each experiment in order to adjust the strength of stimuli applied to pre- and postganglionic nerves. Care was taken to avoid current spread between the stimulating electrodes. After finding the minimal suprathreshold stimulus, the weakest stimulus that always evoked an orthodromic action potential, the stimulus strength was then increased by 1.1-3.0 times in order to be suprathreshold for evoking late slow EPSPs in B and C cells. Using these parameters, the nicotinic EPSP remained suprathreshold in C cells for up to 400 shocks at 20 $\mathrm{Hz}$. For a given cell, one stimulus strength was used to clicit all EPSCs and/or EPSPs.

The number of stimuli $(60,100$, or 200$)$ used to evoke LHRH release was decided for each cell using 1 of 2 methods. The goal was to evoke responses that were large enough for reliable measurement, but small enough so as not to saturate the available $\mathrm{M}$-current. The first method was to perform a 750-msec voltage jump from the resting potential to $-70 \mathrm{mV}$ and measure the amplitude of the slowly relaxing M-current. The number of stimuli was then chosen so that the EPSC evoked by $20-\mathrm{Hz}$ stimulation reduced the available M-current by less than $50 \%$. The second method was to apply 400 or 200 shocks at $20 \mathrm{~Hz}$ in order to evoke a large EPSC. The total number of stimuli to be used was then chosen such that the EPSC evoked by $20-\mathrm{Hz}$ stimulation was still large, but much smaller than that evoked by 400 or 200 shocks, and that $2-\mathrm{Hz}$ stimuli elicited an EPSC large enough for measurements to be reliable.

Rest periods of 5-10 min were allowed between slow synaptic responses and were held constant in each cell. The data were collected from cells in which the recording conditions remained stable for 1-6 hr.

Puffer application of LHRH analogues. Puffer pipettes with tip diameters of $4-8 \mu \mathrm{m}$ were filled with salmon $(50 \mu \mathrm{M})$ or chicken II $(5 \mu \mathrm{M})$ LHRH and positioned approximately $100 \mu \mathrm{m}$ from the somata of impaled ganglion cells. Pressure pulses were supplied using a Picospritzer II (General Valve Co.). For a given cell, pressure was kept constant at 1.4 or 2.8 bar, and the duration of pressure pulses was varied between $5 \mathrm{msec}$ and $11 \mathrm{sec}$.

Solutions and drugs. The normal Ringer's solution contained (in $\mathrm{mM}$ ) $115 \mathrm{NaCl}, 2 \mathrm{KCl}, 1.8 \mathrm{CaCl}_{2}$, and 4 HEPES. The high- and low-Ca ${ }^{2+}$ Ringer's had 5.4 and $0.9 \mathrm{mM} \mathrm{Ca}^{2+}$, respectively. The low-Ca ${ }^{2+}$ Ringer's was supplemented with $1 \mathrm{mM} \mathrm{Mg} \mathrm{Mg}^{2+}$ to maintain the divalent cation concentration. All solutions were adjusted to $\mathrm{pH}$ 7.2-7.3. Atropine sulfate $(1 \mu \mathrm{M})$ was routinely included in all solutions to block muscarinic responses. Salts were obtained from Fisher, atropine from Sigma, and LHRH analogues from Peninsula.
The rate of superfusion was $1.25 \mathrm{ml} / \mathrm{min}$, and the bath volume was about $1 \mathrm{ml}$.

Data collection and analysis. All data were collected and analyzed using interactive programs that were written in BASIC 23 and run on a DEC 11/73 computer and interface (INDEC Systems). Some of the programs were developed with the aid of programs kindly supplied by Dr. Eric Frank.

For orthodromic and antidromic action potentials, the latency, peak amplitude, and duration were measured along with the peak amplitude and duration of the hyperpolarizing afterpotential. In addition, for the orthodromic action potentials, the latency and peak amplitude of the positive waveform after the action potential were also measured. For late slow EPSCs and EPSPs, the delay, peak amplitude, time integral, time to peak, and duration were measured.

Action potentials, slow EPSPs, and some slow EPSCs were recorded without filtering. The voltage-clamp output for other slow EPSCs was filtered at $45 \mathrm{~Hz}$. Action potentials were digitized by the computer at a rate of $6.7 \mathrm{kHz}$. In cells having long hyperpolarizing afterpotentials, the action potential was also sampled at a rate of 4 or $2.9 \mathrm{kHz}$. Slow EPSPs and slow EPSC's were sampled at rates between 6.7 and $1.7 \mathrm{~Hz}$. In each case, the sampling rate was set so that the complete response could be stored in 4 blocks of memory. In voltage-clamp recordings from $C$ cells, the clamp failed to control the membrane potential during the fast nicotinic EPSP and action potential. In these recordings, the rates of rise during the onset of the response were estimated from data segments during interburst intervals and at the end of stimulus trains.

The integrals of LHRHergic responses were measured with a digitizing bit pad and Apple Macintosh computer. In order to compare results from different cells, the peak amplitudes and charges of the EPSCs (and/ or the peak amplitudes and time integrals of EPSPs) in each cell were normalized to those of the EPSC (and/or EPSP) evoked by $20 \mathrm{~Hz}$ continuous stimulation. In high- and low- $\mathrm{Ca}^{2+}$ Ringer's, the magnitudes of all responses were normalized to that of the response evoked by $20-\mathrm{Hz}$ continuous stimulation in the corresponding Ringer's solution.

\section{Results}

\section{Postsynaptic currents reflect $L H R H$ release}

This study was based upon the assumption that relative amounts of synaptically released LHRH could be inferred from the magnitudes of resulting postsynaptic responses. To test this assumption, EPSCs induced by either salmon $(50 \mu \mathrm{M})$ or chicken II $(5 \mu \mathrm{M})$ LHRH applied from a puffer pipette were measured in $4 \mathrm{~B}$ cells and $1 \mathrm{C}$ cell (Fig. 1). Repeated pulses of constant pressure and duration elicited reproducible responses. In all cells, both the peak amplitude and the time integral of the EPSC increased as the pressure pulse duration was increased in the range of $5 \mathrm{msec}$ to $10 \mathrm{sec}$ (Fig. $1 a-c, g-i$ ). Given that the volume ejected from puffer pipettes is proportional to the duration of the pressure pulse (McCaman et al., 1977), this result indicates that both the peak amplitude and the charge of the postsynaptic EPSCs are good indicators of the amount of LHRH released. However, as shown in Figure $1, g-i$, the fact that the normalized peak amplitude is consistently higher than the normalized charge for all pressure pulse durations suggests that charge is a slightly more sensitive measurement than amplitude.

When EPSCs evoked by LHRH puffs of different durations are scaled to the same peak amplitude, the rates of the rising phases are the same (Fig. $1 d-f$ ). Unlike responses to exogenous LHRH, rates of rise varied with stimulus parameters during synaptic responses (see below). Because this could lead to larger discrepancies between peak amplitudes and integrals than the small differences found with puffed LHRH, charge data are presented in the following results:

\section{LHRH release is proportional to the frequency of continuous stimulation}

The dependence of the LHRHergic late slow EPSC upon the frequency of presynaptic nerve stimulation was studied in 19 

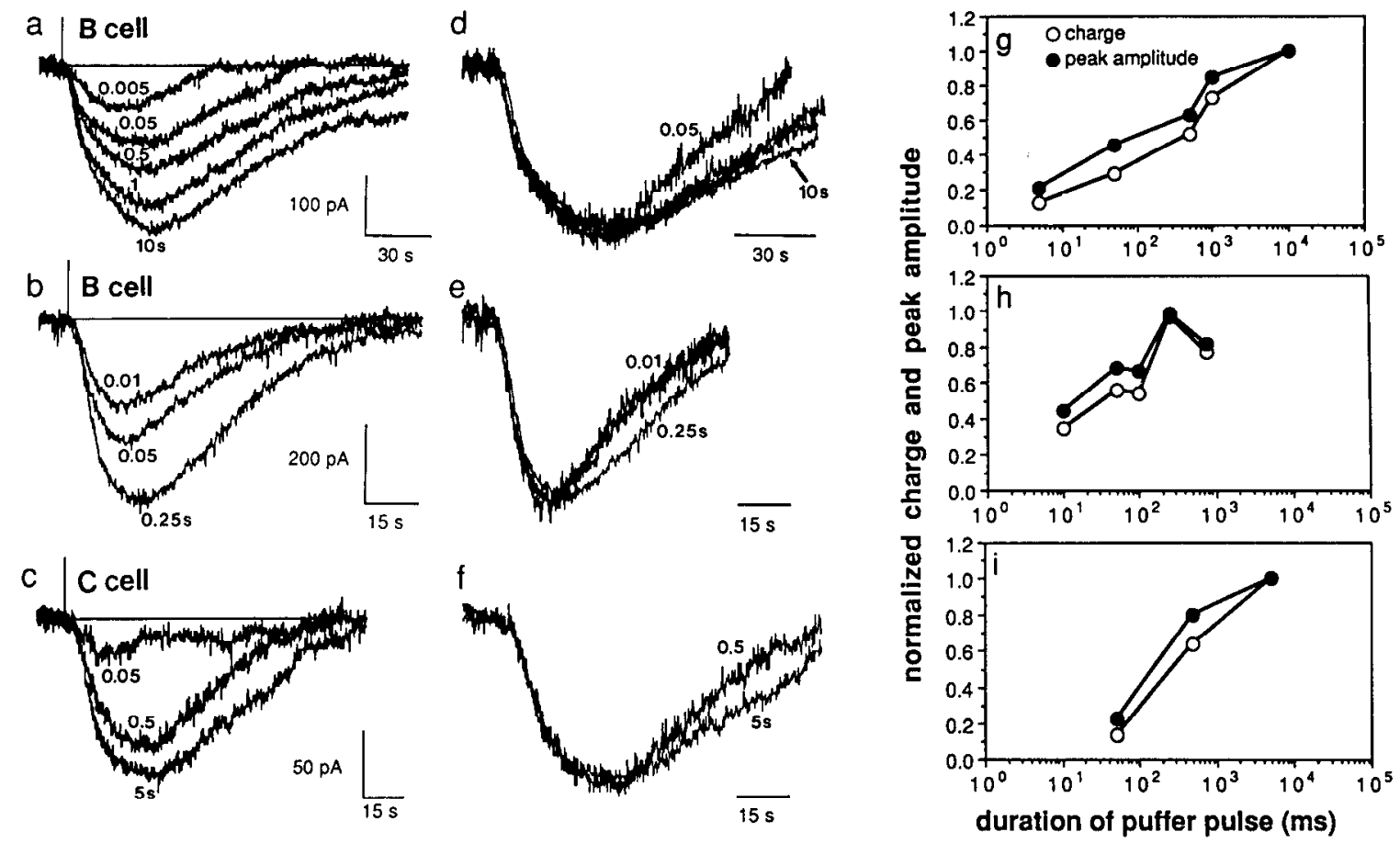

Figure 1. Dose-response relations for applied LHRH in B and C neurons. $a$ and $b$, Superimposed currents recorded from 2 B cells in response to pulses of $5 \mu \mathrm{M}$ chicken II LHRH $(a)$ and $50 \mu \mathrm{M}$ salmon LHRH $(b)$ applied at 1.4 bar. $c$, Currents recorded from a C cell in response to $5 \mu \mathrm{M}$ chicken II LHRH applied at 2.8 bar. Pulse durations in seconds are labeled on all traces. The vertical bar at the left of the traces indicates the start of the pressure pulses. Each trace is representative of 2 responses to the same pulse duration. The magnitudes of the replicate responses were within $7 \%$ of each other. $d-f$, Corresponding currents from $a-c$ have been scaled to the same peak amplitude. Note that rising phases of the responses in each cell follow the same time course, and that the durations increase as the pulse of LHRH is lengthened. Those traces that were not included in panels $d$ and $f$ follow the same trend, but were omitted for visual clarity. $g-i$, Plots of normalized charge and peak amplitude versus puffer-pulse duration for the cells in $a-c$. Each response was normalized to the largest response in that cell and each point is the mean of 2 replicate responses.

fast $\mathrm{B}, 2$ slow $\mathrm{B}$, and $4 \mathrm{C}$ cells. The LHRH containing preganglionic $\mathrm{C}$ pathway was selectively activated in all experiments by stimulating spinal nerves 7 and 8 (see Materials and Methods). The $\mathrm{B}$ cell data has been pooled because no differences were observed between fast and slow B cells. Because the LHRHergic late slow EPSC is the only EPSC studied here, it will be referred to simply as EPSC.

Repetitive stimulation was always required in order to evoke the EPSC. The minimal parameters for eliciting detectable responses in the most sensitive cells were 50 stimuli at $0.5 \mathrm{~Hz}$ or 20 stimuli at $2 \mathrm{~Hz}$. Continuous stimulation $(60,100$, or 200 shocks) at $2 \mathrm{~Hz}$ always elicited a response. At frequencies between 2 and $40 \mathrm{~Hz}$, the magnitude of the EPSC grew as the number of stimuli was increased (Fig. 2a,b). The maximum number of shocks used was 400 . For a given number of stimuli, the magnitude of the EPSC increased with stimulation frequency and saturated around $20 \mathrm{~Hz}$ (Fig. $2 c, e, f, h$ ). At $40 \mathrm{~Hz}$, the magnitude of the EPSC generally declined (6 out of $7 \mathrm{~B}$ cells and 2 out of $2 \mathrm{C}$ cells), as shown in Figure $2 c, e$, and $h$. The charge of EPSCs evoked by $20 \mathrm{~Hz}$ was about 3 and 4 times as large as that evoked by $2 \mathrm{~Hz}$ in B and C cells, respectively (Table 1). In one B cell, the EPSC reached its peak with $5-\mathrm{Hz}$ stimulation, and it was 3.13 times as large as that evoked by $0.5-\mathrm{Hz}$ stimuli.

The reduction of $\mathrm{LHRH}$ release upon $40-\mathrm{Hz}$ stimulation may arise from failure of propagating preganglionic action potentials. At the start of each experiment, several $C$ cells were impaled so that the preganglionic stimulus to spinal nerves 7 and 8 could be adjusted to 1.1-3 times the minimal suprathreshold strength for cvoking a nicotinic EPSP (see Materials and Methods). With single shocks, these fast EPSPs were always suprathreshold for generating a postganglionic action potential. Stimulation at 20 $\mathrm{Hz}$ for 400 stimuli resulted in 400 postganglionic action potentials. At $40 \mathrm{~Hz}, 30-75 \%$ of the stimuli produced subthreshold fast EPSPs. Because each $C$ cell is innervated by 1-3 preganglionic C fibers (Dodd and Horn, 1983b), failure of orthodromic action potentials at $40 \mathrm{~Hz}$ suggests that either some preganglionic C fibers, some synaptic boutons, or both failed to conduct at $40 \mathrm{~Hz}$. This possibility is supported by the observation that compound $\mathrm{C}$-fiber action potentials in the rami of spinal nerves 7 and 8 follow continuous stimulation at frequencies up to 20 $\mathrm{Hz}$, but decrease in magnitude at $40 \mathrm{~Hz}$ (Y. Peng and J. P. Horn, unpublished observations). Alternatively, the releasable stores of ACh and LHRH may be rapidly depleted during $40-\mathrm{Hz}$ stimulation. Although this possibility cannot be ruled out, it seems less likely because postsynaptic responses mediated by both

\begin{tabular}{|c|c|c|}
\hline $\begin{array}{l}\text { Charge ratio } \\
\text { of EPSC }\end{array}$ & $\begin{array}{l}\text { B cells } \\
(N=20)\end{array}$ & $\begin{array}{l}\text { C cells } \\
(N=4)\end{array}$ \\
\hline $20 / 2 \mathrm{~Hz}$ & $2.94 \pm 0.04$ & $3.70 \pm 0.03$ \\
\hline $20 \mathrm{~B} / 2 \mathrm{~Hz}$ & $2.33 \pm 0.29$ & $1.70 \pm 0.28$ \\
\hline $20 \mathrm{~B} / 20 \mathrm{~Hz}$ & $0.66 \pm 0.04$ & $0.44 \pm 0.04$ \\
\hline
\end{tabular}

Data from each cell were normalized to the $20-\mathrm{Hz}$ response. The grouped data are expressed as the mean $\pm \mathrm{SE}$. 

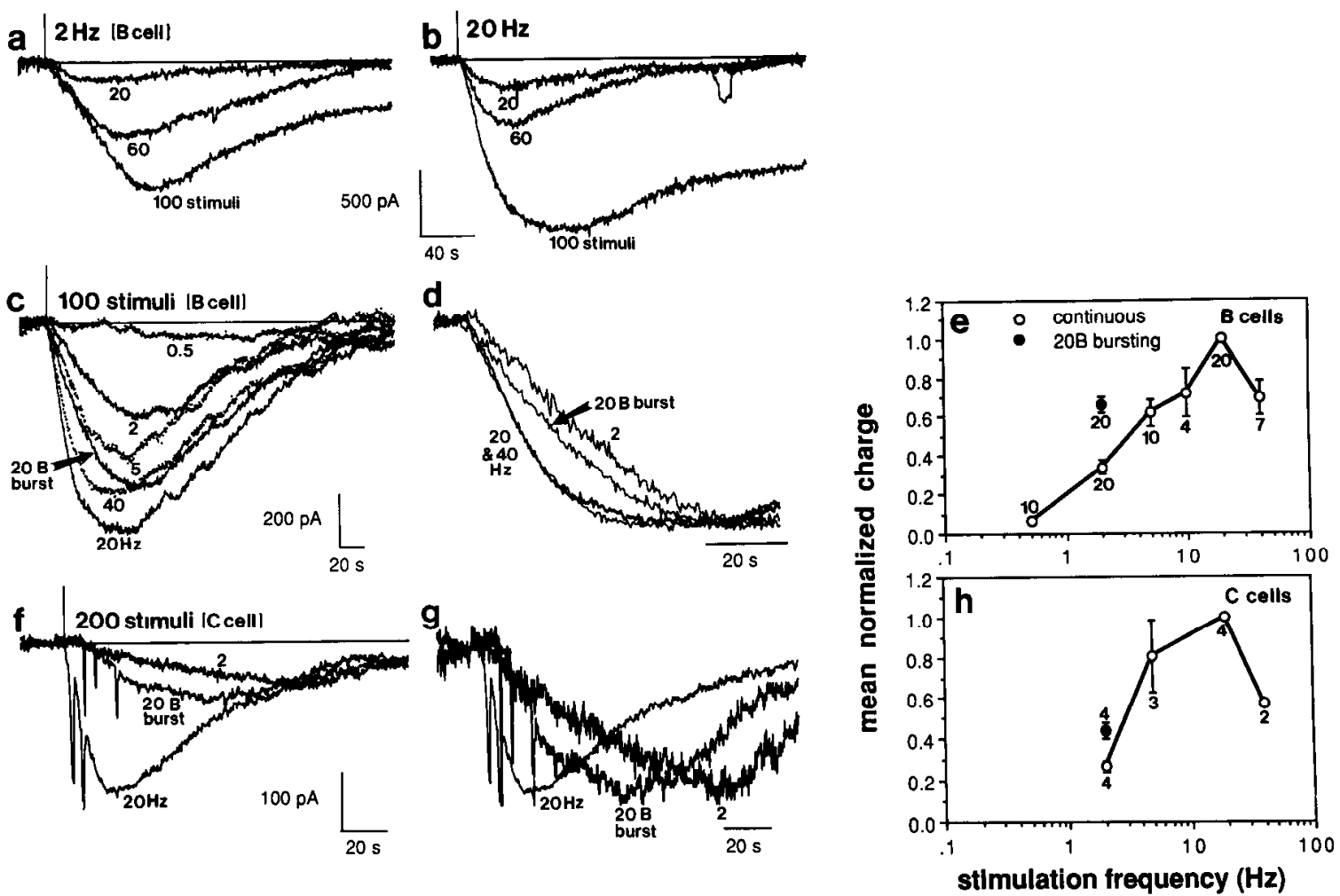

Figure 2. Stimulus dependence of LHRHergic slow EPSCs. The magnitudes of peptidergic EPSCs, evoked in B and C neurons by stimulation of the preganglionic $C$ pathway depend upon the number of stimuli and upon the frequency and burst structure of the stimulation. $a$ and $b$, EPSCs evoked in a B cell by continuous stimulation at $2 \mathrm{~Hz}(a)$ and at $20 \mathrm{~Hz}(b)$ have been supcrimposed at the start of the stimulus trains (vertical bar). The number of stimuli producing each response is labeled on the record. At both frequencies, EPSC amplitude and duration increase with the number of stimuli. $c$, A family of EPSCs recorded from a B cell in response to 100 stimuli. The EPSC labeled $20 B$ burst was evoked by trains of 20 stimuli delivered at $20 \mathrm{~Hz}$ every $10 \mathrm{sec}$. The other EPSCs were evoked by continuous stimulation at the labeled frequencies. $f$, A family of EPSCs recorded from a C cell in response to 200 stimuli. The brief inward current deflections at the start of each response have been truncated for plotting and correspond to the loss of voltage control during the nicotinic EPSPs and action potentials that occurred during the stimulus train. $d$ and $g$. Synaptic currents from $c$ and $f$, respectively, have been scaled to the same peak amplitude. Note that the rate of rise increases with stimulus frequency, and that the frequency dependence is greater in the C cell $(g)$ than in the B cell $(d)$. $e$ and $h$, Mean normalized charge of EPSC versus stimulus frequency from $20 \mathrm{~B}$ cells $(e)$ and $4 \mathrm{C}$ cells $(h)$. For each cell, the charge data were normalized to that of the EPSC evoked by continuous $20-\mathrm{Hz}$ stimulation. Error bars, $1 \mathrm{SE}$. The responses to 20B stimulation have been plotted at their average frequency of $2 \mathrm{~Hz}$. Note that the burst responses in $\mathrm{B}$ and $\mathrm{C}$ cells were larger than those produced by continuous $2-\mathrm{Hz}$ stimulation and smaller than those produced by continuous 20 $\mathrm{Hz}$ stimulation.

transmitters return rapidly to normal levels upon returning to $20-\mathrm{Hz}$ stimulation.

\section{LHRH release is governed by the frequency rather than the bursting structure of stimulation}

Two possible mechanisms can be hypothesized to account for the effectiveness of bursting over continuous stimulation at the same average frequency. Mechanism 1 states that the high frequency of the burst accounts for the increased release, whereas Mechanism 2 postulates that the resting period between successive bursts enhances release.

Mechanism 1 has 2 principal predictions:

1. Stimulation in bursts should be more effective in evoking release than continuous stimulation at the same average frequency. This is also the necessary condition for Mechanism 1 to be true.

2. Stimulation in bursts should be less effective than continuous stimulation at the intraburstal frequency. Prediction 2 in addition to prediction 1 is the necessary and sufficient condition for Mechanism 1 to be true.

Mechanism 2 has 1 principal prediction:
1. Stimulation in bursts should evoke no less release than continuous stimulation at the intraburstal frequency. This is the necessary and sufficient condition for Mechanism 2 to be true. On the other hand, Mechanism 2 has no prediction as to whether bursting should be more effective for evoking release than continuous stimulation at the same average frequency.

EPSCs evoked by bursts of 20 stimuli delivered at $20 \mathrm{~Hz}$ every $10 \mathrm{sec}$ to give an average stimulation frequency of $2 \mathrm{~Hz}$ were compared with EPSCs evoked by continuous 2- and 20$\mathrm{Hz}$ stimulation in $20 \mathrm{~B}$ cells and $4 \mathrm{C}$ cells from the group of 25 cells described in the previous section. This pattern of stimulation will be referred to as $20 \mathrm{~B}$. Based upon the frequency dependence of LHRH release, $20 \mathrm{~B}$ is the best pattern to distinguish Mechanisms 1 and 2. In the preceding section, it was shown that with continuous stimulation the minimal and optimal frequencies for evoking the LHRH response in most cells are 2 and $20 \mathrm{~Hz}$, respectively (Fig. $2 e, h$ ). Because it is the optimal frequency, sustained $20-\mathrm{Hz}$ stimulation should presumably lead most rapidly to depression of release. Given these constraints, Mechanism 1 predicts that comparing 20B bursts with continuous $2-\mathrm{Hz}$ stimulation should be optimal for detecting the dif- 
ference between bursting and continuous stimulation at the same average frequency. On the other hand, Mechanism 2 predicts that comparing the 20B pattern with continuous $20-\mathrm{Hz}$ stimulation should be optimal for detecting the ability of resting periods to relieve factors that depress release without reducing the average frequency below the minimal frequency for continuous stimulation $(2 \mathrm{~Hz})$.

In these $24 \mathrm{~B}$ and $\mathrm{C}$ cells, 20B stimulation evoked EPSCs that were larger than those produced by continuous $2-\mathrm{Hz}$ stimulation and smaller than those produced by continuous $20-\mathrm{Hz}$ stimulation (Fig. $2 c, e, f, h$ ). On average, the EPSCs produced by bursting were twice the size of those produced by continuous $2-\mathrm{Hz}$ stimulation, but only about $2 / 3$ the size of those evoked by continuous $20-\mathrm{Hz}$ stimulation (Table 1 ). In the one B cell having an optimal stimulation frequency of $5 \mathrm{~Hz}$, bursts of 5 shocks delivered at $5 \mathrm{~Hz}$ every $10 \mathrm{sec}$ (5B pattern) were compared to $0.5-\mathrm{Hz}$ and $5-\mathrm{Hz}$ continuous stimuli. The $5 \mathrm{~B} / 0.5-\mathrm{Hz}$ ratio was 1.18 , and the $5 \mathrm{~B} / 5-\mathrm{Hz}$ ratio was 0.38 . Even though the stimulusfrequency dependence for evoking the LHRH response in this cell differed from other cells, the stimulation that contained bursts at the optimal frequency was more effective than continuous stimulation at the average frequency and less effective than continuous stimulation at the optimal frequency. Thus, the necessary and sufficient condition for Mechanism 1 was always met, whereas that for Mechanism 2 was never satisfied.

The interpretation of synaptic currents in terms of release evoked by different patterns of stimulation would be invalid if the postsynaptic response was reduced in the prolonged presence of LHRH. For example, one might imagine that, for a given number of stimuli, the temporal pattern of release evoked by the 20B pattern results in more receptor desensitization than that produced by a briefer train of continuous $20-\mathrm{Hz}$ stimulation. If this were the case, then the smaller responses seen with $20 \mathrm{~B}$ stimulation could be explained as an artifact of the assay rather than a reduction in release. In order to test this possibility, a second set of controls was performed on $4 \mathrm{~B}$ cells. To determine whether postsynaptic responses are sensitive to the temporal pattern of LHRH application, chicken II LHRH was applied using 1 long puff $(11 \mathrm{sec})$ and using 11 short puffs $(1 \mathrm{sec})$ at 10 sec intervals. In 4 out of 4 cells, the response to a series of short puffs was actually larger than that produced by a single puff having the same total duration. Figure $3 a$ illustrates an example of this effect. By contrast, when LHRHergic EPSCs were recorded in the same cell (Fig. $3 b$ ), continuous $20-\mathrm{Hz}$ stimulation evoked a larger response than the $20 \mathrm{~B}$ pattern, as in all other cells (Fig. 2). This supports our interpretation of synaptic currents in terms of release and implies that the comparison of synaptic currents underestimates, if anything, the relative superiority of continuous $20-\mathrm{Hz}$ stimulation for evoking $\mathrm{LHRH}$ release.

A corollary of Mechanism 1 states that bursting with the optimal frequency should be more effective than bursting with other frequencies. This was tested and confirmed in $1 \mathrm{~B}$ cell. In this cell, the $20 \mathrm{~B} / 2-\mathrm{Hz}$ ratio was 2.12 , and the $20 \mathrm{~B} / 20-\mathrm{Hz}$ ratio was 0.81 . When this cell was bathed in high- $\mathrm{Ca}^{2+}$ Ringer's, the optimal frequency for continuous stimulation shifted from 20 to $5 \mathrm{~Hz}$. Meanwhile, the $20 \mathrm{~B} / 2-\mathrm{Hz}$, ratio was reduced to 0.98 , and the $20 \mathrm{~B} / 20-\mathrm{Hz}$ ratio was reduced to 0.57 . When bursts of stimuli containing the new optimal frequency $(5 \mathrm{~Hz})$ were applied, they were found to be more effective than the $20 \mathrm{~B}$ pattern. The new pattern contained 2-sec bursts at $5 \mathrm{~Hz}$ delivered every $5 \mathrm{sec}$ (average frequency, $2 \mathrm{~Hz}$ ). It evoked EPSCs that were 1.42

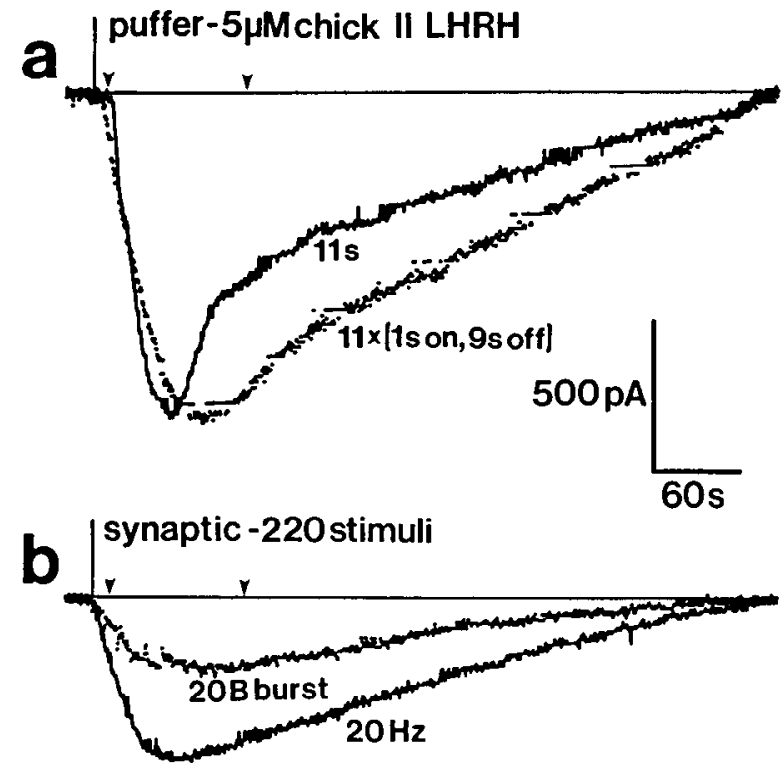

Figure 3. Currents recorded from a $\mathbf{B}$ cell in response to single and multiple exposures to LHRH released from puffer pipette $(a)$ and nerve terminals $(b)$. a, Superimposed currents recorded in response to $5 \mu \mathrm{M}$ chicken II LHRH delivered in an 11 -sec pulse and in a series of 11 1 -sec pulses separated by $9-\sec$ intervals. The vertical bar at the left of the traces indicates the start of the pressure pulses ( $1.4 \mathrm{bar})$, and the arrowheads indicate the termination of the pulses. $b$, Superimposed EPSCs recorded from the same cell as in $a$. Two hundred twenty stimuli were applied to the preganglionic C pathway in a continuous $20-\mathrm{Hz}$ train and in the 20B pattern. The vertical bar at the left of the traces indicates the first stimulus and the arrowheads indicate the last stimulus for each EPSC.

times the size of those evoked by continuous $2-\mathrm{Hz}$ stimulation and 0.78 times the size of those evoked by continuous $5-\mathrm{Hz}$ stimulation. Thus, shifting the optimal frequency for continuous stimulation also shifted the optimal intraburstal frequency.

Another corollary of Mechanism 1 is that the bursting pattern containing the optimal frequency and having an average frequency equal to the minimal frequency should produce the maximal increase of release when compared to continuous stimulation at the average frequency. As implied above, this corollary contributed to the rationale for choosing 20B stimulation to test Mechanisms 1 and 2 . In $1 \mathrm{C}$ cell, the $20 \mathrm{~B} / 2-\mathrm{Hz}$ ratio was 2.51 , while bursting with 20 shocks delivered at $20-\mathrm{Hz}$ every $2 \mathrm{sec}$ evoked an EPSC only 1.09 times that evoked by continuous 10 $\mathrm{Hz}$ stimulation (Fig. 4).

A corollary of Mechanism 2 states that, for a given intraburstal frequency and burst duration, increasing the interburst resting period should enhance release. This was tested in a B and a C cell using 1 -sec bursts at $20 \mathrm{~Hz}$. In the B cell, bursting stimulation with interburst intervals of 9 and $3 \mathrm{sec}$ were found to evoke responses having magnitudes within $4 \%$ of each other. Both patterns evoked EPSCs smaller ( 0.74 and 0.77 , respectively) than that produced by continuous $20-\mathrm{Hz}$ stimulation (Fig. $5 a, b$ ) and larger than that produced by continuous $2-\mathrm{Hz}$ stimulation. Similarly, in the $\mathrm{C}$ cell, bursting stimulation with interburst intervals of 9 and $1 \mathrm{sec}$ were found to evoke responses having magnitudes within $4 \%$ of each other. Again, both patterns evoked EPSCs smaller ( 0.48 and 0.46 , respectively) than those produced by continuous $20-\mathrm{Hz}$ stimulation (Fig. $5 c, d$ ) and larger than that produced by continuous $2-\mathrm{Hz}$ stimulation.

These examples further demonstrate that activity within bursts 
200 stimuli [ C cell]
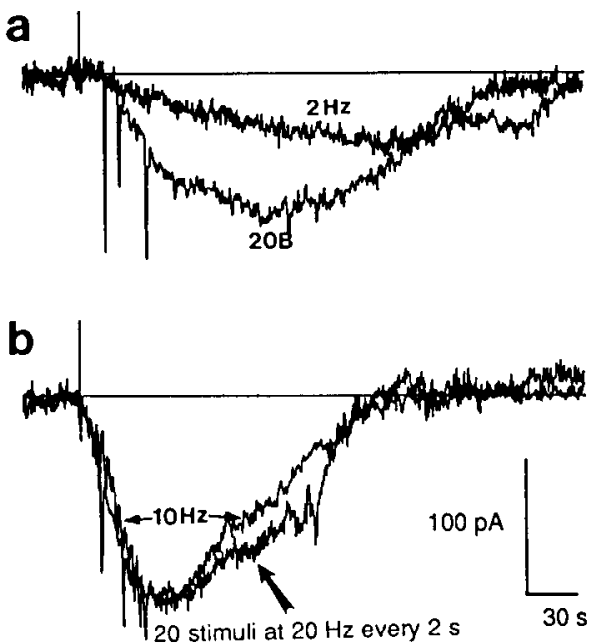

Figure 4. Comparison between different patterns of bursting and continuous stimulation at same average frequency. Superimposed EPSCs recorded in a $\mathrm{C}$ cell in response to 200 stimuli delivered continuously at $2 \mathrm{~Hz}$ and in the $20 \mathrm{~B}$ burst pattern $(a)$, and continuously at $10 \mathrm{~Hz}$ and in bursts of 20 shocks delivered at $20 \mathrm{~Hz}$ every $2 \mathrm{sec}(b)$, are shown. An EPSC evoked in this cell by continuous $20-\mathrm{Hz}$ stimulation is shown in Fig. $5 d$. Note that the disparity between responses to bursts containing the optimal frequency $(20 \mathrm{~Hz})$ and to continuous stimulation is greater when the average frequency of the burst pattern is equal to the minimal frequency for continuous stimulation. However, the responses to both burst patterns were smaller than that evoked by continuous $20-\mathrm{Hz}$ stimulation.

not the quiescence between them dictates release. High-frequency continuous stimulation is more effective than bursting for evoking LHRH release.

\section{Stimulus frequency governs the rate of $L H R H$ release}

In addition to enhancing the amount of LHRH being released, the rates of rise of EPSCs increased monotonically with stimulus frequency between 2 and $20 \mathrm{~Hz}$ (Fig. $2 d, g$ ). The data for 5 and $10 \mathrm{~Hz}$ were omitted from Figure $2, d$ and $g$, for visual clarity.
These rates reached a plateau at $20 \mathrm{~Hz}$. Even though the magnitude of the current declined at $40 \mathrm{~Hz}$ (Fig. $2 c, e$ ), its rate of rise remained the same as for $20-\mathrm{Hz}$ stimulation (Fig. $2 d$ ). Bursting stimulation evoked EPSCs having rates of rise faster than those evoked by continuous stimuli with the same average frequency, but slower than those elicited by continuous stimuli with the intraburstal frequency (Fig. $2 d, g$ ). This dependence of the EPSC rate of rise upon stimulation frequency was stronger in $\mathrm{C}$ cells than in B cells (Fig. $2 d, g$ ).

Assuming that the onset rate of the EPSC reflects the rate of agonist concentration increase at receptors, these data can be interpreted in terms of rates of release and diffusion distances for LHRH. For a given cell, the diffusion distance between release sites and receptors is constant. The ratcs of EPSC onset should therefore reflect rates of release. The data thus indicate that the rate of release is governed by stimulus frequency rather than by burst structure.

The observed differences in the stimulus dependence in the onset rates of postsynaptic responses between $B$ and $C$ cells and between synaptic and puffer responses are consistent with differences in the diffusion distances for LHRH. As the diffusion distance between the source of the agonist and its target increases, the sensitivity of the cell to the rate of release should decrease. Consistent with the fact that $\mathrm{C}$ cells, but not B cells, are contacted by preganglionic synaptic boutons containing LHRH (Jan et al., 1980a; Horn and Stofer, 1988), C cells had a stronger frequency dependence than $B$ cells in the onset rate of synaptic responses. When applying LHRH from puffer pipettes, diffusion distances were many times larger than in synaptic release. Moreover, becausc puffer pulscs were delivered at constant pressure, it seems likely that the rate of release from a pipette was relatively constant for various pulse durations. Both factors probably contributed to the observed insensitivity of onset rates of puffer responses to pulse duration (Fig. $1 d-f$ ).

\section{The magnitudes and onset rates of EPSPS are also governed by stimulus frequency}

In several cells, the stimulus dependence of the unclamped LHRHergic slow EPSP was examined and found to be qualitatively similar to that of the synaptic currents. Figure 6 illus-
Figure 5. Varying interburst interval has little effect on charge carried by synaptic currents. $a$, Superimposed EPSCs recorded from a $B$ cell in response to 200 stimuli delivered in bursts of 20 shocks at $20 \mathrm{~Hz}$ every $10 \mathrm{sec}$ and every 4 sec. $b$, An EPSC evoked in the same B cell by continuous $20-\mathrm{Hz}$ stimulation. $c$, Superimposed EPSCs recorded from a $C$ cell in response to 200 stimuli delivered in bursts of 20 shocks at 20 $\mathrm{Hz}$. The interburst interval was varied between 9 and 1 sec. $d$, An EPSC evoked in the same $C$ cell by continuous 20 $\mathrm{Hz}$ stimulation. In both cells, note that 2 bursting patterns evoked responses of similar charge ( $a, 1$ vs. $2 ; c, 1$ vs. 3 ) even though the resting periods differed by factors of $3(a)$ and $9(c)$. The response to continuous stimulation at the intraburstal frequency $(b, d)$ was greater than that produced by both burst patterns $(a, c)$
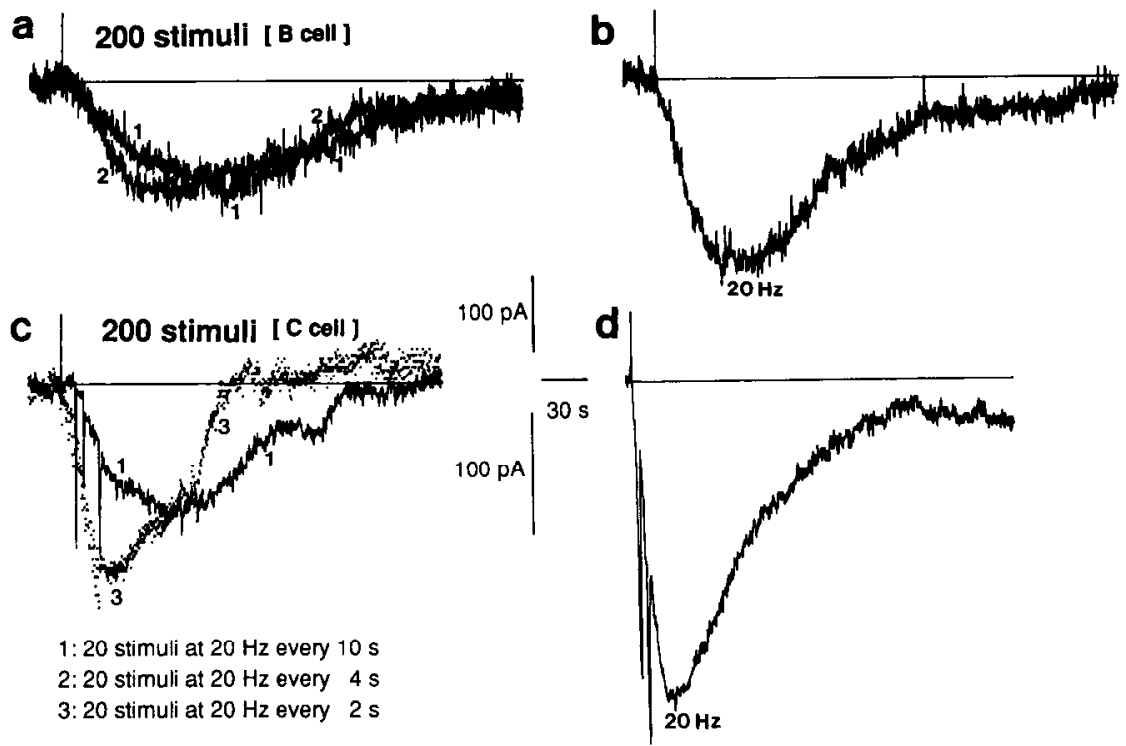

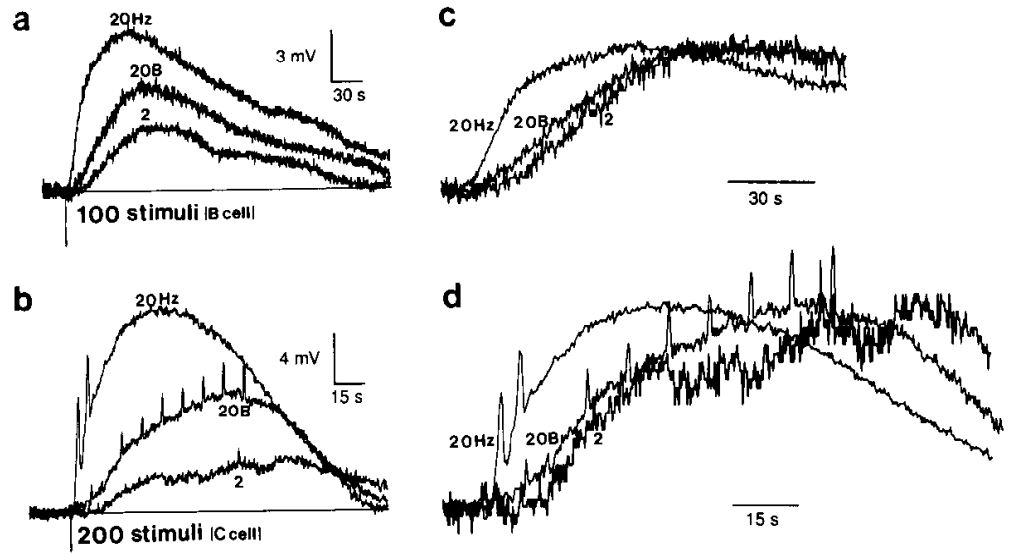

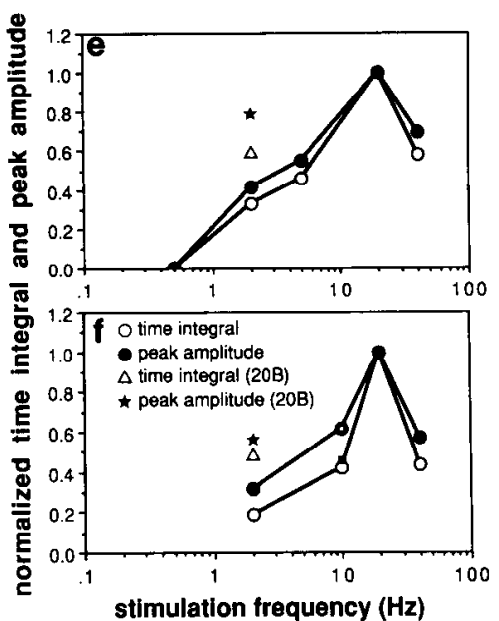

Figure 6. Dependence of LHRHergic synaptic potentials upon stimulation parameters resembles that of synaptic currents. $a$ and $b$, Superimposed EPSPs recorded from a B cell $(a)$ and a C cell $(b)$ in response to continuous stimulation $(2$ and $20 \mathrm{~Hz})$ and $20 \mathrm{~B}$ stimulation. As with synaptic currents (see Fig. 2), the magnitude of the synaptic potential evoked by the $20 \mathrm{~B}$ stimulation lies between those produced by continuous stimulation at the intraburstal frequency $(20 \mathrm{~Hz})$ and at the mean frequency of the burst pattern $(2 \mathrm{~Hz}), c$ and $d$, The synaptic potentials from the B cell (c) and $C$ cell $(d)$ were scaled to the same peak amplitude. Note the rates of rise increase with stimulus frequency. $e$ and $f$, Plots of normalized time integrals and peak amplitudes versus stimulation frequency for synaptic potentials from the cells in $a$ and $b$. In each cell, all responses were normalized to that evoked by continuous $20-\mathrm{Hz}$ stimulation. The responses evoked by the $20 \mathrm{~B}$ stimulation have been plotted at their mean frequency $(2 \mathrm{~Hz})$. Data for an EPSC evoked by bursts of 20 stimuli delivered at $20 \mathrm{~Hz}$ every 2 sec were also plotted at their mean frequency (10 $\mathrm{Hz}$ ). These points (small open circle, small solid circle) overlap those for responses to continuous stimulation.

trates in a $\mathrm{B}$ and a $\mathrm{C}$ cell the dependence of the EPSP upon stimulus frequency and the relative efficacy of $20 \mathrm{~B}$ stimulation.

\section{Concentration of extracellular $\mathrm{Ca}^{2+}$ affects the stimulation-frequency dependence of $L H R H$ release}

To distinguish possible mechanisms that may account for the frequency dependence of LHRH release, the effects of extracellular $\mathrm{Ca}^{2+}$ upon release were measured. Varying stimulus frequency results in different temporal patterns of terminal depolarization. Moreover, it has been reported that increasing the stimulation frequency broadens action potentials in some peptide secreting terminals (Gainer et al., 1986; Bourque, 1990). Thus, the stimulus-frequency dependence of LHRH release might reflect the kinetics of voltage-dependent processes mediating peptide release. The most important voltage-dependent process for release, if not the only one, is the influx of $\mathrm{Ca}^{2+}$ into terminals via voltage-gated $\mathrm{Ca}^{2+}$ channels. Indeed, broadening of the ter- minal action potential upon high-frequency stimulation was abolished in 0 extracellular $\mathrm{Ca}^{2+}$ (Bourque, 1990). Voltage-gated $\mathrm{Ca}^{2+}$ channels having different kinetics are reported to dominate synaptic transmission in different systems (Rane et al., 1987; Hirning et al., 1988). If extracellular $\mathrm{Ca}^{2+}$ concentration was changed moderately such that the driving force for $\mathrm{Ca}^{2+}$ ions was changed, but not the dynamics of terminal depolarization, then one could test whether or not the frequency dependence of release is tightly coupled to the dynamics of terminal depolarization. If this dependence is intrinsic, then response magnitudes for all the frequencies should increase or decrease by the same factor when the extracellular $\mathrm{Ca}^{2+}$ concentration is raised or reduced. In other words, the normalized frequencyresponse curve for LHRH release should be unaffected by extracellular $\mathrm{Ca}^{2+}$.

The effects of extracellular $\mathrm{Ca}^{2+}$ upon the frequency dependence of LHRH release were evaluated by measuring in indi-

200 stimuli [ B coll] ]
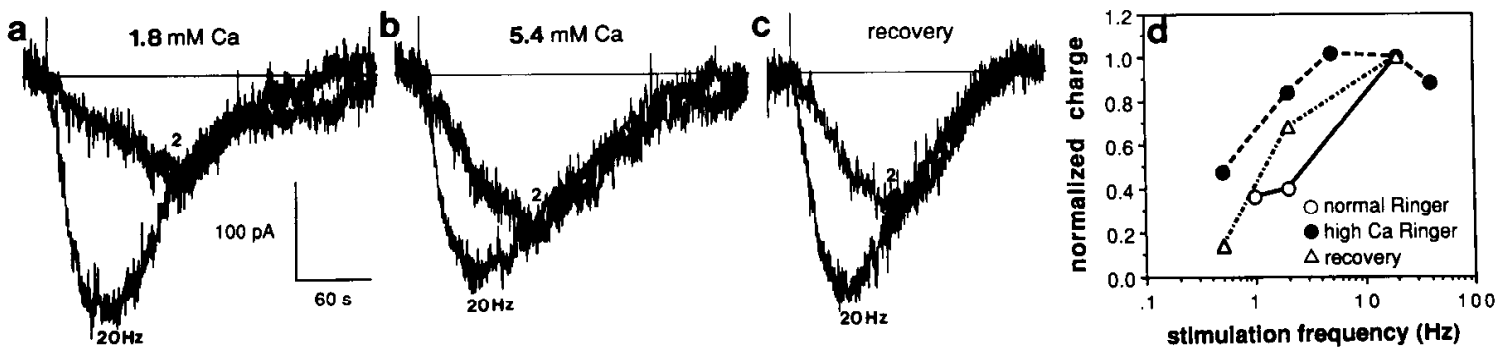

Figure 7. Elevated extracellular $\mathrm{Ca}^{2+}$ shifts dependence of EPSC magnitude upon frequency of continuous stimulation. $a-c$, Superimposed EPSCs evoked in a B cell by 2 - and $20-\mathrm{Hz}$ stimulation in $1.8 \mathrm{mM} \mathrm{Ca}^{2+}$ Ringer's $(a), 5.4 \mathrm{~mm} \mathrm{Ca}^{2+}$ Ringer's $(b)$, and back to $1.8 \mathrm{~mm} \mathrm{Ca}^{2+} \mathrm{Ringer}^{\prime} \mathrm{s}(\mathrm{c})$. Note that high $\mathrm{Ca}^{2+}$ enhances the response to $2 \mathrm{~Hz}$, but has little effect on the response to $20 \mathrm{~Hz}$. $d$, The relation between normalized synaptic charge and stimulation frequency. Data collected in each Ringer's solution were normalized to the 20-Hz response. 


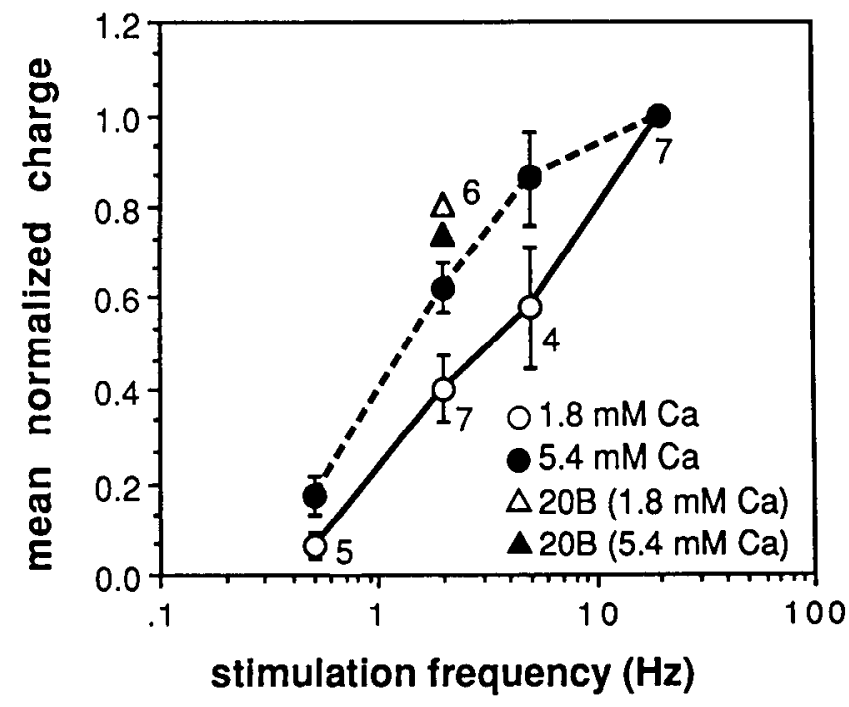

Figure 8. Effects of $5.4 \mathrm{mM} \mathrm{Ca}^{2+}$ on stimulation-frequency dependence of EPSCs in $7 \mathrm{~B}$ cells. In each cell, EPSCs were recorded in normal and high- $\mathrm{Ca}^{2+}$ Ringer's, and data recorded under each condition were normalized to the $20-\mathrm{Hz}$ responses. The number of cells is labeled for each mean. Error bars are 1 SE. Means of responses to $20 \mathrm{~B}$ stimulation in normal and high- $\mathrm{Ca}^{2+}$ Ringer's recorded in 6 of the neurons are plotted at the average frequency of this pattern $(2 \mathrm{~Hz})$. Error bars were omitted from the $20 \mathrm{~B}$ points because these were analyzed as 2 groups (see last paragraph of Results). vidual $\mathrm{B}$ and $\mathrm{C}$ cells the frequency-response relations in both normal $(1.8 \mathrm{mM})$ and high- $\mathrm{Ca}^{2+}(5.4 \mathrm{mM}$ in $7 \mathrm{~B}$ and $2 \mathrm{C}$ cells $)$ or low- $\mathrm{Ca}^{2+}(0.9 \mathrm{mM}$ in $2 \mathrm{~B}$ cells) Ringer's. Indirect evidence from control recordings in other postganglionic $C$ cells suggests that increasing the $\mathrm{Ca}^{2+}$ concentration from 1.8 to $5.4 \mathrm{mM}$ may have little, if any, effect on the time course of terminal depolarization. As judged from fast nicotinic EPSPs, high $\mathrm{Ca}^{2+}$ did not change the stimulus threshold for $\mathrm{ACh}$ release by preganglionic $\mathrm{C}$ fibers. The duration of the antidromic action potential in $\mathrm{C}$ cells was also unaffected (with an accuracy of $0.15 \mathrm{msec}$ ).

High- $\mathrm{Ca}^{2+}$ Ringer's shifted the normalized frequency-response curve to the left (Figs. 7, 8, 9d-f). The primary effect of high $\mathrm{Ca}^{2+}$ was to enhance responses to low-frequency stimulation with relatively little effect on responses to high-frequency stimulation (Figs. 7, $9 d-f$ ). When $0.5-\mathrm{Hz}$ stimuli were applied to 5 of the $7 \mathrm{~B}$ cells in normal $\mathrm{Ca}^{2+}$, detectable responses were observed in 3 cells. After shifting to high $\mathrm{Ca}^{2+}$, all 5 cells responded. In another B cell, an EPSC was evoked by an even lower frequency $(0.25 \mathrm{~Hz})$, but only after shifting from normal to high $\mathrm{Ca}^{2+}$. Thus, it appears that high $\mathrm{Ca}^{2+}$ lowered the minimal frequency for evoking LHRH release. In addition, high $\mathrm{Ca}^{2+}$ increased the $2 / 20-\mathrm{Hz}$ ratio by $0.22 \pm 0.04$ in $7 \mathrm{~B}$ cells and by 0.46 and 0.18 in $2 \mathrm{C}$ cells. In some of these cells, the optimal frequency was shifted to below $20 \mathrm{~Hz}$ (Figs. $7 d, 9 f$ ). In the one B cell having an optimal stimulus frequency of $5 \mathrm{~Hz}$ in normal Ringer's, the $0.5 / 5-\mathrm{Hz}$ ratio was increased from 0.32 to 0.89 in high-Ca ${ }^{2+}$ Ringer's.

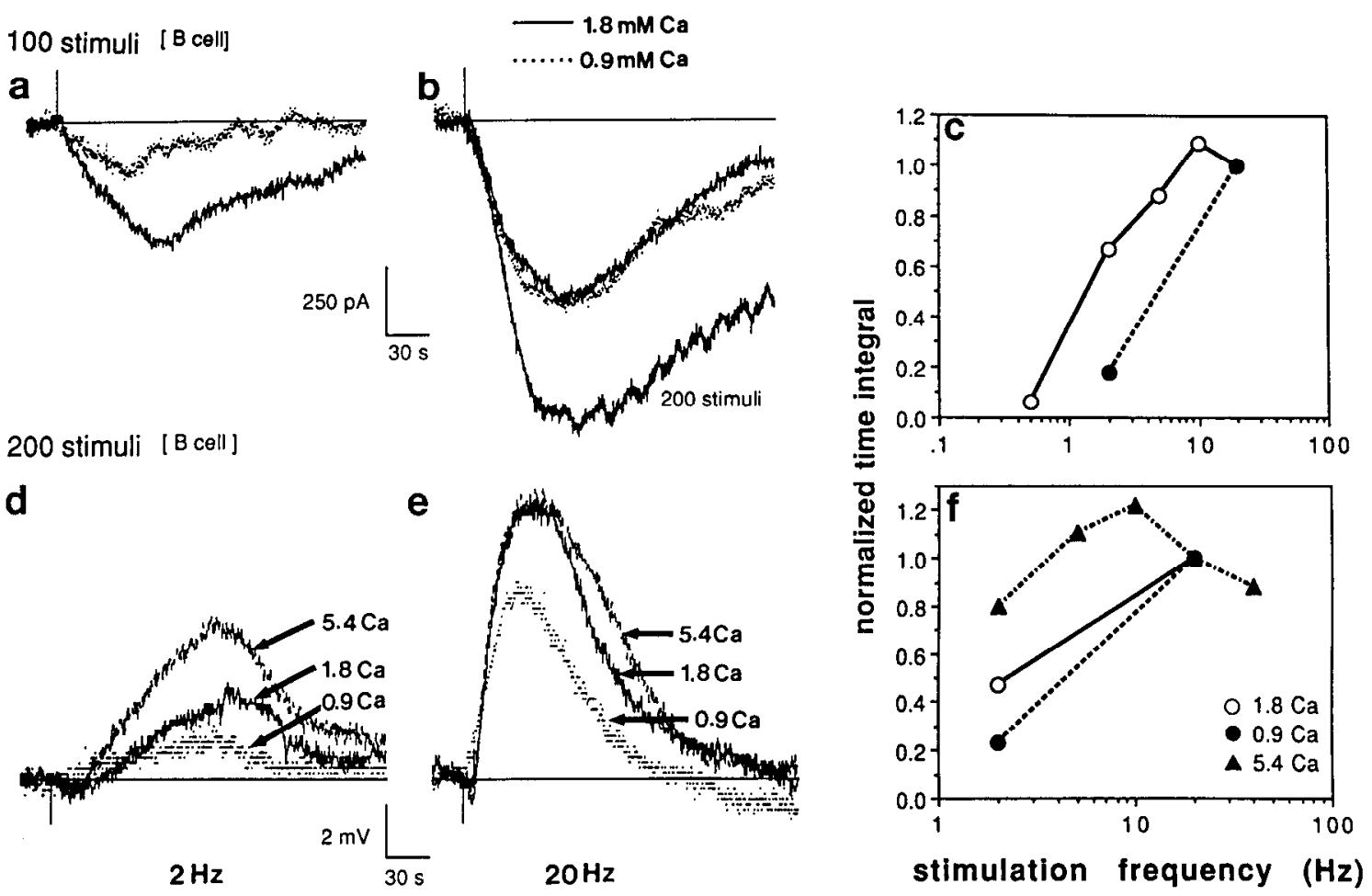

Figure 9. Comparison of synaptic responses in normal, reduced, and elevated extracellular $\mathrm{Ca}^{2+}, a$ and $b$, Synaptic currents from a $\mathrm{B}$ cell in response to 100 stimuli at $2 \mathrm{~Hz}(a)$ and $20 \mathrm{~Hz}(b)$ in normal and low-Ca ${ }^{2+}$ Ringer's. An EPSC evoked by 200 stimuli at $20 \mathrm{~Hz}$ is also shown in $b$. $d$ and $e$, Synaptic potentials from another B cell in response to 200 stimuli at $2 \mathrm{~Hz}(c)$ and $20 \mathrm{~Hz}(d)$ in normal and high- and low-Ca ${ }^{2+} \mathrm{Ringer}$ 's. Note that the largest effects of altered $\mathrm{Ca}^{2+}$ were upon responses to 2-Hz stimulation. $c$ and $f$, Plots of normalized time integral versus stimulation frcquency for the cells in $a$ and $b(c)$ and $d$ and $e(f)$. Data collected in each Ringer's solution were normalized to the 20-Hz response. 
Low-Ca ${ }^{2+}$ Ringer's shifted the frequency-response relation in the opposite direction. In $2 \mathrm{~B}$ cells that were examined, the $2 / 20-\mathrm{Hz}$ ratio decreased by 0.24 and 0.25 , respectively (Fig. 9). Shifting to low- $\mathrm{Ca}^{2+}$ Ringer's reduced the EPSC evoked by 2 $\mathrm{Hz}$ (Fig. 9a,d), but had a smaller effect upon the response to 20$\mathrm{Hz}$ stimulation (Fig. 9b,e). The response to 200 shocks at 20 $\mathrm{H}_{z}$ in Figure $9 b$ demonstrates that the 100-shock stimulus used in this experiment were not saturating at the pre- or postsynaptic level.

The shifts in the normalized frequency-response curves caused by varying extracellular $\mathrm{Ca}^{2+}$ concentration suggest that LHRH release does not depend intrinsically upon the dynamics of terminal depolarization, but simply on the availability of $\mathrm{Ca}^{2+}$.

The efficacy of $20 \mathrm{~B}$ stimulation in normal and in high $\mathrm{Ca}^{2+}$ was examined in $6 \mathrm{~B}$ cells (Fig. 8). In 2 cells, the $20 \mathrm{~B} / 20-\mathrm{Hz}$ ratio increased in high $\mathrm{Ca}^{2+}$ by 0.19 and 0.30 , but remained less than 1 . In these cells, $20 \mathrm{~Hz}$ remained the optimal frequency, yet lower frequencies became relatively more effective. For example, the $2 / 20-\mathrm{Hz}$ ratio increased. This observation supports Mechanism 1, because the burst pattern remained more effective than continuous stimulation at the average frequency, and thereby accounts for the increased $20 \mathrm{~B} / 20-\mathrm{Hz}$ ratio. By contrast, the $20 \mathrm{~B} / 20-\mathrm{Hz}$ ratio decreased in high $\mathrm{Ca}^{2+}$ in the other 4 cells from $0.85 \pm 0.08$ to $0.64 \pm 0.09$, while $0.5 / 20-, 2 / 20-$, and $5 / 20-\mathrm{Hz}$ ratios all increased. However, when 3 of these cells were further examined, the optimal frequency was found to have shifted from 20 to $5 \mathrm{~Hz}$. Because the bursting stimulation pattern (20B) no longer contained the optimal frequency, our theory provides an explanation for the decreased $20 \mathrm{~B} / 20-\mathrm{Hz}$ ratio (see first corollary of Mechanism 1). In summary, high $\mathrm{Ca}^{2+}$ did not alter the basic relation between the efficacies of bursting and continuous stimulation.

\section{Discussion}

The results of this study are consistent with those of Andersson et al. (1982), Bicknell et al. (1982), and Lundberg et al. (1986, 1989). As reported for other neuropeptides, we found bursting to be always more effective in evoking LHRH release than continuous stimulation at the average frequency of the burst pattern. Bursting patterns of activity are physiologically relevant to peptide release because they occur naturally in autonomic (Hallin and Torebjork, 1974) and hypothalamic neurons (Poulain et al., 1977). However, in order to understand the mechanism of peptide release, the present experiments were designed to distinguish the effects of intraburstal frequency and interburst intervals. The finding that continuous stimulation at the intraburstal frequency always evokes larger EPSCs than those produced by bursts, regardless of the resting period duration, demonstrates that firing frequency dictates LHRH release. At first glance, this might appear to contradict the effects of bursting stimulation upon vasopressin release that were observed by Cazalis et al. (1985). However, they utilized stimulus trains containing many more stimuli (i.e., 1400), longer bursts (25 sec), and longer interburst intervals (21-180 sec). Consequently, factors including accumulation of extracellular $\mathrm{K}^{+}$and depletion of the releasable transmitter pool may contribute to their observations, whereas this study concentrated on more rapid processes that may affect release, probably including $\mathrm{Ca}^{2+}$-channel inactivation. Finally, Cazalis et al. (1985) measured the overflow of peptide from superfused tissue, which could reflect the contributions of synaptic and nonsynaptic release, whereas we measured only peptide release that could be detected by postsynaptic receptors.
The dependence of LHRH release by preganglionic $\mathrm{C}$ fibers upon the frequency of continuous stimulation is remarkably similar to that reported for other neuropeptide-releasing systems. In normal Ringer's, the minimal frequency that always evoked LHRHergic EPSCs was $2 \mathrm{~Hz}$, the optimal frequency was $20 \mathrm{~Hz}$, and the response declined by about $30 \%$ at $40 \mathrm{~Hz}$ (Fig. 2). The same relation was observed both in $B$ cells and $C$ cells. The decline in LHRH release at $40 \mathrm{~Hz}$ is likely to arise from presynaptic conduction failure (see Results). Analogous observations were reported for vasopressin release by terminals in the mouse neurohypophysis, where Gainer et al. (1986) found $20 \mathrm{~Hz}$ to be the optimal stimulation frequency, with declines of $18 \%$ at $30 \mathrm{~Hz}$ and $33 \%$ at $40 \mathrm{~Hz}$. Bicknell (1988) observed a similar frequency dependence for vasopressin release. In the myenteric plexus, Morita and North (1985) measured the frequency dependence of continuous stimulation for evoking slow EPSPs. Although their data is very similar to our observations, the contribution and identity of the peptide(s) mediating the myenteric slow EPSP is less certain (Furness and Costa, 1987; Willard, 1990).

By examining the onset of LHRHergic EPSCs, it has been possible to infer that the rate of LHRH release also increases with stimulation frequency. The rate of release rises in parallel with the amount of release and peaks at $20 \mathrm{~Hz}$ (Fig. $2 d, g$ ). Even though the amount of release declines at $40 \mathrm{~Hz}$, the rate stays high (Fig. $2 d$ ). Comparable observations have not been made in other systems.

An intriguing hypothesis that has been previously invoked to account for the efficacy of bursting activity upon peptide release posits that resting periods between bursts allow for relief of presynaptic $\mathrm{Ca}^{2+}$-channel inactivation (Hirning et al., 1988). Based on other studies (Jones and Marks, 1989; Lemos and Nowycky, 1989), one would suspect that the 9-sec resting periods employed here were sufficient to relieve such inactivation. Because $20-\mathrm{Hz}$ continuous stimulation was more efficacious than any bursting pattern that tested here, the inactivation hypothesis is untenable for explaining the stimulus dependence of peptide release in this system.

The effects of altered extracellular $\mathrm{Ca}^{2+}$ concentration demonstrate that LHRH release is not tightly coupled to particular frequencies or bursting patterns of stimulation. Changing the $\mathrm{Ca}^{2+}$ concentration had large effects at low frequencies of stimulation and relatively little effect at $20 \mathrm{~Hz}$ (e.g., Fig. 9b,e). This observation suggests the existence of a process(es) that antagonizes the alterations of driving force produced by changes in extracellular $\mathrm{Ca}^{2+}$ concentration. Depletion of the releasable transmitter pool and/or saturation of the postsynaptic response might account for the relative constancy of EPSCs evoked by $20 \mathrm{~Hz}$ in different concentrations of $\mathrm{Ca}^{2+}$ (Fig. 9b,e). However, the number of stimuli used to study each cell was chosen to avoid these possibilities (see Materials and Methods). This is also illustrated in Figure $9 b$, where larger responses were observed at $20 \mathrm{~Hz}$ when the number of stimuli was increased. Alternatively, $\mathrm{Ca}^{2+}$-dependent inactivation of presynaptic $\mathrm{Ca}^{2+}$ channels (Eckert and Chad, 1984; Kramer and Zucker, 1985; Fox et al., 1987) might serve to counter changes in the extracellular concentration of $\mathrm{Ca}^{2+}$. If this were the case, then one could imagine that, in high $\mathrm{Ca}^{2+}$, the effect of altered driving force would be dominant at low stimulus frequencies, and the effect of inactivation would be dominant at high stimulus frequencies. This would account for the reduction in the minimal stimulus frequency for release in high $\mathrm{Ca}^{21}$, for the large $\mathrm{Ca}^{21}$ 
sensitivity of release evoked by $2-\mathrm{Hz}$ stimulation (Figs. $7 d ; 9 a, d$ ), and for the relative $\mathrm{Ca}^{2+}$ insensitivity of release evoked by 20$\mathrm{Hz}$ stimulation. However, resolution of these issues will require measurements of intracellular $\mathrm{Ca}^{2+}$ concentrations in terminals during stimulation and information about the kinetics of presynaptic $\mathrm{Ca}^{2+}$ channels in this system.

In addition to LHRH, preganglionic $C$ neurons in the bullfrog corelease ACh (Jan and Jan, 1982). This study confirms and extends the previous observation that the stimulus requirements for evoking release of these 2 transmitters are quite different. Unlike LHRH, ACh release evoked by a single shock is sufficient to activate suprathreshold nicotinic EPSPs, and brief trains of 10 shocks at $10 \mathrm{~Hz}$ are sufficient to maximally activate muscarinic receptors mediating the slow IPSP (Dodd and Horn, 1983b). Thus, the frequency of firing in preganglionic $C$ fibers appears to be one fine-tuned mechanism that regulates the differential release of 2 cotransmitters. Low frequencies and brief periods of activity favor purely cholinergic transmission, while high frequencies and longer periods of activity favor coactivation of cholinergic and peptidergic transmission. Similar behavior has been reported in Aplysia neurons by Whim and Lloyd (1989).

Because the stimulus dependence of LHRHergic slow EPSPs is similar to that of the underlying synaptic currents (Fig. 6), our data provide insight into the preganglionic coding of information and the integrative function of ganglionic cotransmission under more physiological conditions.

In summary, stimulus frequency, not bursting structure, governs peptide release. Furthermore, because the dependence of release upon stimulus frequency can be altered by extracellular $\mathrm{Ca}^{2+}$ concentration, peptide release does not depend intrinsically upon stimulation frequency, but simply on the availability of $\mathrm{Ca}^{2+}$.

\section{References}

Adams PR, Brown DA, Constanti A (1982a) M-currents and other potassium currents in bullfrog sympathetic neurons. J Physiol (Lond) 330:537-572.

Adams PR, Brown DA, Constanti A (1982b) Pharmacological inhibition of the M-current. J Physiol (Lond) 332:223-262.

Andersson P-O, Bloom SR, Edwards AV, Jarhult J (1982) Effects of stimulation of the chorda tympani in bursts on submaxillary responses of the cat. J Physiol (Lond) 322:469-483.

Barrett EF, Magleby KL (1976) Physiology of cholinergic transmission. In: Biology of cholinergic function (Goldberg AM, Hanin I, eds), pp 29-100. New York: Raven.

Bickncll RJ (1988) Optimizing release from peptide hormone secretory nerve terminals. J Exp Biol 139:51-65.

Bicknell RJ, Flint APF, Leng G, Sheldrick EL (1982) Phasic pattern of electrical stimulation enhances oxytocin secretion from the isolated neurohypophysis. Neurosci Lett 30:47-50.

Bley KR, Tsien RW (1988) LHRH and substance P inhibit $\mathrm{N}$ - and L-type calcium channels in frog sympathetic neurons. Biophys J 53: $235 a$.

Bosma MM, Hille B (1989) Protein kinase C is not necessary for peptide-induced suppression of $M$ current or for desensitization of the peptide receptors. Proc Natl Acad Sci USA 86:2943-2947.

Bourque CW (1990) Intraterminal recordings from the rat neurohypophysis in vitro. J Physiol (Lond) 421:247-262.

Brethes D, Dayanithi G, Letellier L, Nordmann JJ (1987) Depolarization-induced $\mathrm{Ca}^{2+}$ increase in isolated neurosecretory terminals measured with fura-2. Proc Natl Acad Sci USA 84:1439-1443.

Cazalis M, Dayanithi G, Nordmann J (1985) The role of patterned burst and interburst interval on the excitation-coupling mechanism in the isolated rat neural lobe. J Physiol (Lond) 369:45-60.

Dekin MS, Richerson GB, Getting PA (1985) Thyrotropin-releasing hormone induces rhythmic bursting in neurons of the nucleus tractus solitarius. Science 229:67-69.

Dodd J, Horn JP (1983a) A reclassification of B and C neurones in the ninth and tenth paravertebral sympathetic ganglia of the bullfrog. J Physiol (Lond) 334:255-269.

Dodd J, Horn JP (1983b) Muscarinic inhibition of sympathetic C neurones in the bullfrog. J Physiol (Lond) 334:271-291.

Eckert R, Chad JE (1984) Inactivation of Ca channels. Prog Biophys Mol Biol 44:215-267.

Ewald DA, Pang I-H, Sternweis PC, Miller RJ (1989) Differential G protein-mediated coupling of neurotransmitter receptors to $\mathrm{Ca}^{2+}$ channels in rat dorsal root ganglion neurons in vitro. Neuron 2:11851193.

Finkel AS, Redman SJ (1985) Optimal voltage clamping with single microelectrode. In: Voltage and patch clamping with microelectrode (Smith TG Jr, Lecar H, Redman SJ, Gage PW, eds), pp 47-94. Bethesda: American Physiology Society.

Fox AP, Nowycky MC, Tsien RW (1987) Kinetic and pharmacological properties distinguishing three types of calcium currents in chick sensory neurones. J Physiol (Lond) 394:149-172.

Furness JB, Costa M (1987) The enteric nervous system. New York: Churchill Livingstone.

Gainer H, Wolfe SA, Obaid AL, Salzberg BM (1986) Action potentials and frequency-dependent secretion in the mouse neurohypophysis. Neuroendocrinology 43:557-563.

Griffith WH, Hills JM, Brown DA (1988) Substance P-mediated membrane currents in voltage-clamped guinea pig inferior mesenteric ganglion cells. Synapse 2:432-441.

Gross RA, Macdonald RL (1987) Dynorphin A selectively reduces a large transient (N-type) calcium current of mouse dorsal root ganglion neurons in cell culture. Proc Natl Acad Sci USA 84:5469-5473.

Hallin RG, Torebjork HE (1974) Single unit sympathetic activity in human skin nerves during rest and various manoeuvres. Acta Physiol Scand 92:303-317.

Hirning LD, Fox AP, McCleskey E, Olivera BM, Thayer SA, Miller RJ, Tsien RW (1988) Dominant role of $\mathrm{N}$-type $\mathrm{Ca}^{2+}$ channels in evoked release of norepinephrine from sympathetic neurons. Science 239:5761.

Horn JP, Stofer WD (1988) Double labeling of the paravertebral sympathetic C system in the bullfrog with antisera to LHRH and NPY. J Auton Nerv Syst 23:17-24.

Ikeda SR, Schofield GG (1989) Somatostatin blocks a calcium current in rat sympathetic ganglion neurones. J Physiol (Lond) 409:221-240.

Jacquin T, Champagnat J, Madamba S, Denavit-Saubie M, Siggins GR (1988) Somatostatin depresses excitability in neurons of the solitary tract complex through hyperpolarization and augmentation of $I_{M}$, a non-inactivating voltage-dependent outward current blocked by muscarinic agonists. Proc Natl Acad Sci USA 85:948-952.

Jan LY, Jan YN (1982) Peptidergic transmission in sympathetic ganglia of the frog. J Physiol (Lond) 327:219-246.

Jan YN, Jan LY, Kuffler SW (1979) A peptide as a possible transmitter in sympathetic ganglia of the frog. Proc Natl Acad Sci USA 76:15011505.

Jan LY, Jan YN, Brownfield MS (1980a) Peptidergic transmitters in synaptic boutons of sympathetic ganglia. Nature 288:380-382.

Jan YN, Jan LY, Kuffler SW (1980b) Further evidence for peptidergic transmission in sympathetic ganglia. Proc Natl Acad Sci USA 77: 5008-5012.

Jones SW (1985) Muscarinic and peptidergic excitation of bull-frog sympathetic neurons. J Physiol (Lond) 366:63-87.

Jones SW (1987) A muscarine-resistant M-current in C cells of bullfrog sympathetic ganglia. Neurosci Lett 74:309-314.

Jones SW, Marks TN (1989) Calcium currents in bullfrog sympathetic neurons, II. Inactivation. J Gen Physiol 94:169-182.

Kramer RH, Zucker RS (1985) Calcium-induced inactivation of calcium current causes the inter-burst hyperpolarization of Aplysia bursting neurones. J Physiol (Lond) 362:131-160.

Lemos JR, Nowycky MC (1989) Two types of calcium channels coexist in peptide-releasing vertebrate nerve terminals. Neuron 2:1419-1426.

Lundberg JM, Stjarne L (1984) Neuropeptide Y (NPY) depresses the secretion of ${ }^{3} \mathrm{H}$-noradrenaline and the contractile response evoked by field stimulation, in rat vas deferens. Acta Physiol Scand 120:477479 .

Lundberg JM, Rudehill A, Sollevi A, Theodorsson-Norheim E, Hamberger B (1986) Frequency- and reserpine-dependent chemical cod- 
ing of sympathetic transmission: differential release of noradrenaline and neuropeptide $Y$ from pig spleen. Neurosci Lett 63:96-100.

Lundberg JM, Rudehill A, Sollevi A, Fried G, Wallin G (1989) Corelease of neuropeptide $\mathrm{Y}$ and noradrenaline from pig spleen in vivo: importance of subcellular storage, nerve impulse frequency and pattern, feedback regulation and resupply by axonal transport. Neuroscience 28:475-486.

McCaman RE, McKenna DG, Ono JK (1977) A pressure system for intracellular and extracellular ejections of picoliter volumes. Brain Res 136:141-147.

Mihara S, North RA, Surprenant A (1987) Somatostatin increases an inwardly rectifying potassium conductance in guinea-pig submucous plexus neurones. J Physiol (Lond) 390:335-355.

Morita K, North RA (1985) Significance of slow synaptic potentials for transmission of excitation in guinea-pig myenteric plexus. Neuroscience 14:661-672.

Mudge AW, Leeman SE, Fischbach GD (1979) Enkephalin inhibits release of substance $P$ from sensory neurons in culture and decreases action potential duration. Proc Natl Acad Sci USA 76:526-530.

North RA, Williams JT, Surprenant A, Christie MJ (1987) $\mu$ and $\delta$ receptors belong to a family of receptors that are coupled to potassium channels. Proc Natl Acad Sci USA 84:5487-5491.
Peng Y, Horn JP (1989) High frequency continuous stimulation is more effective than bursts for evoking LHRH release in bullfrog sympathetic ganglia. Soc Neurosci Abstr 15:473.

Poulain DA, Wakerley JB, Dyball RE (1977) Electrophysiological differentiation of oxytocin- and vasopressin-secreting neurones. Proc $\mathbf{R}$ Soc Lond [Biol] 196:367-384.

Rane SG, Holz IV GG, Dunlap K (1987) Dihydropyridine inhibition of neuronal calcium current and substance $P$ release. Pfluegers Arch 409:361-366.

Schofield GG, Ikeda SR (1988) Neuropeptide Y blocks a calcium current in C cells of bullfrog sympathetic ganglia. Eur J Pharmacol 151:131-134.

Silinsky EM (1985) The biophysical pharmacology of calcium-dependent acetylcholine secretion. Pharmacol Rev 37:81-132.

Whim MD, Lloyd PE (1989) Frequency-dependent release of peptide cotransmitters from identified cholinergic motor neurons in Aplysia. Proc Natl Acad Sci USA 86:9034-9038.

Willard AL (1990) A vasoactive intestinal peptide-like cotransmitter at cholinergic synapses between rat myenteric neurons in cell culture. J Neurosci 10:1025-1034.

Zucker RS (1989) Short-term synaptic plasticity. Annu Rev Neurosci 12:13-31. 